\title{
Parenting styles and Internet use
}

\section{Ana Tur-Porcar}

University of Valencia, Spain

Correspondence

Ana Tur-Porcar, Department of Basic Psychology, University of Valencia, Blasco Ibañez Av. 21, Valencia, 46010, Spain.

Email: ana.tur@uv.es

\begin{abstract}
The Internet has become the most popular way for young people to communicate with one another. Recent data indicate that $95 \%$ of students have Internet access. This study examined the links between Internet use and the parenting styles that shape parent-child interactions. Empirical analysis showed that Internet use accounts for the majority of adolescents' leisure time. The neglecting parenting style has the strongest relationship with addictive Internet use by adolescent girls and boys. For boys, addictive Internet use is also related to a combination of different parenting styles resulting from inconsistencies and contradictions between parents.
\end{abstract}

\section{KEYWORDS}

adolescence, authoritarian, authoritative, Internet, neglecting, parenting, permissive

\section{1 | INTRODUCTION}

In today's society, technological advances, the structure of the work environment, and unstable employment have led to a family structure in which children spend an unsuitable amount of time without parental supervision. Meanwhile, the sociotechnological advances of the digital era have enabled easy access to information via the Internet. This easy access can be positive if the Internet is used for educational purposes, but it can also lead to indiscriminate Internet use.

Indiscriminate Internet use can hamper motor, emotional, cognitive, and language development, affecting one's ability to do sport, build personal relationships, and express needs. The Internet has become the most popular way for young people to communicate with each other. This tendency means that in many cases, youngsters' leisure time may be restricted to cyberspace. Instagram, Facebook, Twitter, FaceTime, Snapchat, Spotify, WhatsApp, Pinterest, Vimeo, Tinder, Vine, and Skype are examples of the new media adolescents use to interact with one another.

The rise of social networks has been accompanied by an increase in adolescents' access to the Internet. A report by the OECD (2015) revealed that $91 \%$ of 15 -year-olds had mobile phones with Internet access. In 2017, the MECD reported that $95 \%$ of the students had Internet-ready devices, predominantly mobile phones (MECD, 2017).

Ferreiro, Salgado, Harris, Tobío, and Boubeta (2017) found that Spanish adolescents use the Internet mainly for instant messaging through services such as WhatsApp (76\%) and access to social networks (67\%) principally through visual Web sites such as Instagram and Pinterest. Online shopping is also becoming popular (12\%). Nevertheless, adolescents, especially girls (59\%), use the Internet to search for information relating to their studies.
Different people have different buying behaviors, which are somewhat linked to one another: planned buying, compulsive buying, and impulsive buying (Kacen, Hess, \& Walker, 2012). Adolescents' buying tends to be impulsive. Adolescents yearn for products because of what they represent rather than their function (Baudrillard, 2007). Adolescent buying is expressed through social relationships, and it promotes certain values through mass culture. This form of buying involves little reflection. It is therefore useful to link Internet use to production (Gonçalves, Rey-Martí, Roig-Tierno, \& Miles, 2016). Scholars have found that innovation, new technologies, and social media are essential for firm survival (Ribeiro Soriano \& Huarng, 2013).

Against this backdrop, parents' concerns about the amount of time their children spend on the Internet are growing. More than $25 \%$ of parents are highly worried about their children's Internet use. This concern is not about shopping. Parents' concerns are focused principally on children's access to violent or sexual content (65\%), becoming a target of grooming (60\%), access to information about anorexia or suicide (55\%), and suffering bullying by other children (47\%) (Jiménez, 2011). Parents with an uninvolved parenting style (neglecting) or permissive parenting style are unconcerned by rules and grant their children complete freedom. These children are more prone to Internet addiction (Chou \& Lee, 2017; Eastin, Greenberg, \& Hofschire, 2006). Boys perceive permissive or neglecting parenting more than girls do, whereas girls perceive greater support and greater control (Özgür, 2016; TurPorcar, Mestre, Samper, \& Malonda, 2012). Despite these findings, no study has linked parenting to Internet use by Spanish adolescents. To fill this research gap, this article addresses the following question: To what extent can parents help children regulate their Internet use?

This article analyzes the relationship between Internet use by Spanish adolescents and the parenting styles that shape parent-child 
interactions. Section 2 explores the role of parenting styles in adolescents' Internet access. Section 3 describes the quantitative analysis approach and qualitative method (fuzzy-set qualitative comparative analysis) and presents the results of the analysis. Finally, Section 4 discusses the study's conclusions, limitations, and research opportunities.

\section{INTERNET ACCESS AND PARENTING STYLES}

The rise of social networks has been accompanied by an increase in the number of adolescents with Internet access. According to a report by the OECD (2015), between 2012 and 2015, the time that adolescents in OECD countries spent on the Internet increased by $25 \%$. This increase equated to 65 minutes at the weekend and 59 minutes during the week. The report revealed that $91 \%$ of 15 -year-olds had mobile phones with Internet access. In 2017, the MECD found that $95 \%$ of students had Internet-ready devices, principally mobile phones (MECD, 2017). In addition, $61 \%$ of children began using the Internet before the age of 10 years ( $17 \%$ by the age of 6 years), and $69 \%$ reported that they felt very bad if they could not access the Internet, indicating their dependence on the Internet (OECD, 2015).

Regarding daily Internet use, for example, $22 \%$ of adolescents reported that they spent more than six hours a day online, $18 \%$ between four and six hours, $26 \%$ between two and four hours, and $18 \%$ between one and two hours. Conversely, only $2 \%$ of adolescents reported having no Internet access. Among young people in the OECD countries, young Spaniards are fifth in terms of time spent online. During the week, they spend an average of 167 minutes a day online. At the weekend, the average is 215 minutes. These figures are slightly higher than the mean across all OECD countries (OECD, 2015).

Recent studies have shown that the time adolescents spend online and the frequency with which they access the Internet is similar for boys and girls (Rial, Gómez, Braña, \& Varela, 2014). There are, however, differences in the reasons why girls and boys use the Internet. Boys are more likely to use the Internet to play online games, place bets, or view pornography. Girls tend to use the Internet for social relationships, instant messaging, email, and social networks (Ak, Koruklu, \& Yilmaz, 2013; Critselis et al., 2013; Pujazon-Zazik, \& Park, 2010). Girls and boys both use the Internet to search for information relating to their studies. This is especially true of girls.

In today's society, the family is still considered the principal agent of socialization. Within the family, children internalize behavioral principles in accordance with society and culture. The way a family behaves is influenced by social organization (i.e., the exosystem consisting of institutions and the mass media) and beliefs, values, and culture (i.e., the macrosystem) (Bonfrenbenner, 1987, 2005). The family is therefore subject to social change and the influence of these changes on people and on the modus vivendi.

In this context, parent-child relationships are molded by parenting styles, which shape parent-child interactions and share close ties with the emotional milieu of the family environment (Darling \& Steinberg, 1993). Therefore, parenting styles affect the nature of parent-child interactions and offer a framework for establishing parenting practices.

According to socialization theory, parents and children are active agents who interact bidirectionally, thereby establishing the quality of interactions (Bandura, 1986, 2006; Hoffman, 2002; Kuczynski \& Parkin, 2007). Parents and children are message issuers and message receivers who reach an understanding through a back-and-forth process of question and answer. For this process to work, individuals need to adopt a reflective, metacognitive stance toward their own and others' behaviors, build meaning, and create expectations regarding behavior (Benbassat \& Priel, 2012; Grusec, Goodnow, \& Kuczynski, 2000).

In this context, the intrapersonal and interpersonal dimensions are important. The intrapersonal dimension relates to the ability to know and understand oneself. The interpersonal dimension alludes to the ability to know and understand the feelings and needs of others (Benbassat \& Priel, 2012). Parents whose actions are guided by knowledge and understanding of their children's needs can achieve a warmer, more comprehensive parenting style (Laursen \& Collins, 2009; Rubin, Wojslawowicz, Rose-Krasnor, Booth-LaForce, \& Burgess, 2006; Zimmer-Gembeck, Waters, \& Kindermann, 2010).

\section{1 | Parenting styles}

According to empirical evidence, parenting style has two dimensions represented by two orthogonal axes: the responsiveness axis and the demandingness axis (Maccoby \& Martin, 1983). The interaction between the two axes yields four parenting styles: authoritative, authoritarian, neglecting, and permissive (Baumrind, 1991, 1996; Schaefer, 1965).

Authoritative or competent parenting has high levels of warmth, support, and communication as well as control and disciplinary limits. Authoritative parents tend to encourage bidirectional communication aimed at well-being within the family unit. In contrast, authoritarian parenting is based on the imposition of rules with a high level of control and little support or warmth. Parents with an uninvolved parenting style neglect their role as parents and let their children be. These parents act in an authoritarian manner when events do not transpire as they would like. Uninvolved parenting (neglecting) is characterized by little warmth and little control. Finally, permissive or indulgent parenting is characterized by letting children be but demonstrating care and being attentive to the needs of the child. Permissive parenting is characterized by low control and relatively high levels of warmth (Chou \& Lee, 2017; Tur-Porcar, Mestre, \& Llorca, 2015).

In recent years, scholars have found empirical evidence of certain relationships between parenting style and children's Internet use. Studies have shown inverse relationships between the emotional warmth of the family and Internet use (Chou \& Lee, 2017; Eijnden, Spijkerman, Vermulst, Rooij, \& Engels, 2010). In contrast, authoritarian parenting, which is based on psychological control, promotes Internet use. Compulsive Internet use is positively related to authoritarian and neglecting parenting styles (Chou \& Lee, 2017; Eastin et al., 2006; Huang et al., 2010). Authoritarian parenting involves strict control of children, which seems to positively affect Internet addiction. Parenting 
practices that focus on the imposition of rules seem to encourage Internet addiction (Ko et al., 2015). Likewise, a neglecting parenting stylewhere parents show little interest in the needs of their children and grant them complete freedom to do as they please-also encourages compulsive Internet use (Eastin et al., 2006).

Control in parenting is a characteristic of authoritarian and authoritative parenting. Parents with an authoritative parenting style foster emotional warmth within the family unit. They also instill discipline through rules, which leads to an attitude of control over the child's behavior. Findings on this issue are inconsistent. For example, psychologists have found that the authoritative parenting style encourages rational, responsible Internet use, especially when parents are concerned about promoting good qualitative communication on Internet use that meets standards (Ko et al., 2015). Yet others have found that authoritative parenting is related to compulsive Internet use, especially when parents aim at controlling the amount of time the child uses the Internet and impose unjustified restrictions (Xiuqin et al., 2010). The hypotheses summarize the theory discussed in this section.

Hypothesis 1: Parenting styles are related to Internet use in middle and late adolescence. Authoritarian, neglecting, and permissive parenting styles encourage Internet use by adolescents.

Hypothesis 2: There are gender differences in the relationships between parenting style and Internet use. For boys, authoritarian, neglecting, and permissive parenting styles have a greater influence. Girls tend to perceive authoritative parenting. These perceptions are related to Internet use.

\section{3 | METHOD}

\section{1 | Instruments}

The Parenting Styles and Parent-Child Relationships Questionnaire was adapted from the Children's Reports of Parental Behavior Inventory (Schaefer, 1965; Spanish version by Tur-Porcar et al., 2015). The questionnaire has 38 items. The questionnaire uses children's perceptions to evaluate the parenting styles that shape parent-child relationships. Example items are, "Likes to talk to me," "Often praises me," and "Loses his (her) temper with me when I don't follow advice." Respondents chose one of three alternatives ranging from never (1) to always (3). When answering, respondents were asked to think about the father and mother separately. The questionnaire items can be grouped into the following factors. (i) Authoritative parenting consists of maternal and paternal emotional support, expressions of love and support, and encouragement of independence through disciplinary criteria. (ii) Authoritarian parenting consists of relationships based on strict control, irritability, and rejection toward the child. (iii) Permissiveness and neglecting parenting consists of extreme autonomy and an absence of rules and disciplinary criteria (anything goes), leading children to perceive a lack of care for their needs. Cronbach's alpha for each of the four factors was as follows: authoritative parenting $=0.83$ (paternal) and 0.85 (maternal); authoritarian parenting $=0.71$ (paternal) and 0.73 (maternal); neglecting parenting $=0.62$ (paternal) and 0.71 (maternal); and permissiveness $=0.61$ (paternal) and 0.65 (maternal).

The Internet Use Questionnaire has five items. For the first two items, adolescents gave details on the number of times per week they accessed the Internet and played online games. Adolescents chose from four options: never, once or twice a week, three or four times a week, or every day. Next, adolescents ranked their priorities. The third item assessed their buying behaviors. For the fourth item, adolescents responded to the statement, "I like to shop online." For the fifth item, adolescents responded to the statement, "I think the Internet is the best way to shop." For the third, fourth, and fifth items, adolescents ranked their opinions on a five-point scale: not at all $=0 \%$, hardly $=$ up to $25 \%$, moderately $=$ up to $50 \%$, quite a lot $=$ up to $75 \%$, or a lot $=$ up to $100 \%$. Cronbach's alpha for the third, fourth, and fifth items about shopping online was 0.80 .

\section{2 | Participants}

Participants were 433 adolescents aged $15-18$ years $(M=16.21$; $S D=0.799$ ), $46 \%$ of whom were girls and $54 \%$ boys. They were enrolled in compulsory secondary education or the baccalaureate program at public and semi-private schools in Valencia (Spain). The distribution of the father's education level was as follows: $0.9 \%$ of fathers had no basic primary studies, $17.8 \%$ had primary or lower secondary studies, $35.8 \%$ had upper secondary studies, and $45.5 \%$ had a university education. The distribution of the mother's education level was as follows: $1.4 \%$ of mothers had no basic primary studies, $12.0 \%$ had primary or lower secondary studies, $32.3 \%$ had upper secondary studies, and $54.3 \%$ had a university education. The percentage of respondents living with both parents was 77.1 . Of the remaining $22.9 \%$, the parents were separated or divorced in $17.8 \%$ of cases, the parents were absent for other reasons in $3.3 \%$ of cases, and one or more parents had died in $1.8 \%$ of cases.

\section{3 | Procedure}

The schools authorized the evaluation. Teachers, families, and the adolescents themselves received a presentation explaining the research. Participation was voluntary. The principles stipulated in the Declaration of Helsinki regarding research with human participants were respected. Confidentiality and anonymity were guaranteed. The instruments were administered to participants in groups in the school classroom during school hours. Instructions to complete the questionnaire were given orally. The evaluation sessions lasted approximately 45 minutes.

\subsection{Data analysis}

Quantitative and qualitative analyses were conducted. Quantitative analysis consisted of tests of differences between means. The Student's $t$-test was used to test for differences between girls and boys and between middle adolescence (14-16 years) and late adolescence (17-18 years). Qualitative analysis consisted of fuzzy-set qualita- 
tive comparative analysis (fsQCA). fsQCA is a suitable method for studying social phenomena characterized by complex causality. It identifies configurations (combinations) of conditions that are sufficient or necessary for an outcome of interest to occur (Legewie, 2013; Schneider \& Wagemann, 2012). A condition is sufficient if its presence leads to the outcome. A condition is necessary if it is always present when the outcome occurs. fsQCA thus uses set theory to identify the causal conditions (or configurations thereof) that lead to an outcome of interest (Fiss, 2011).

First, the data are calibrated. This process consists of transforming the variables into set-based conditions. Following calibration, it is possible to determine whether, for each condition, a case is fully in a set (membership value 1) or fully outside a set (membership value 0) (Ragin \& Fiss, 2008). In fsQCA, membership can also be partial, so membership values may also be between 0 and 1 .

The truth table is then built. The truth table has $2^{k}$ rows, where $k$ is the number of causal conditions analyzed in the study (Fiss, 2011). The truth table is reduced following the method described by Ragin and Fiss (2008). Finally, the truth table is transformed into configurations (of conditions) that lead to the outcome.

The conditions considered in the analysis were four parenting styles: neglecting (fs_negle), permissive (fs_perm), authoritative (fs_autho), and authoritarian (fs_control). Age was also considered (fs_age). Age was calibrated as being "absent" when the adolescent was aged between 14 and 16 years-that is, adolescents who are not yet self-sufficient. Age was considered to be "present" for adolescents aged between 17 and 18 years-that, late adolescence. The outcome was Internet use as the preferred leisure activity.

\section{RESULTS}

\section{1 | Descriptive analysis and gender differences}

First, analysis of differences between means was conducted using the Student's $t$-test for independent samples. This test was performed to detect gender differences in the variables. The analysis failed to show significant differences between boys and girls in terms of their Internet use and Internet buying behaviors. However, boys played online games significantly more than girls did ( $t=-0.87 ; p=0.000$ ). There were also significant differences in the belief that buying online is the best way to shop ( $t=3.18 ; p=0.002)$ because it is cheaper $(t=2.33 ; p=0.02)$. Boys had significantly higher scores than girls in all of these cases.

Analysis of the differences between means for the subsamples of middle adolescence (14-16 years) and late adolescence (17-18 years) was then conducted. The analysis showed significant differences between the two subsamples in terms of shopping online $(t=-2.59$; $p=0.010)$, liking this form of shopping $(t=-2.02 ; p=0.044)$, considering shopping online the best way to shop $(t=-2.49 ; p=0.013)$, and saving money when shopping online $(t=3.86 ; p=0.000)$. Significant differences were not found for Internet use or for playing online games.

Analysis was conducted to explore parenting styles and the way adolescents perceive their relationships with both parents. The Student's $t$-test for independent samples revealed few differences
TABLE 1 Analysis of necessary conditions for the girl adolescent model

\begin{tabular}{|lll|}
\hline Conditions tested & Consistency & Coverage \\
\hline fs_perm & 0.539199 & 0.697814 \\
\hline$\sim f s \_p e r m$ & 0.583705 & 0.676801 \\
\hline fs_autho & 0.417234 & 0.670963 \\
\hline fs_autho & 0.693135 & 0.684037 \\
\hline fs_control & 0.371012 & 0.674872 \\
\hline fs_control & 0.743963 & 0.685432 \\
\hline fs_negle & 0.499793 & 0.692113 \\
\hline$\sim f s \_n e g l e$ & 0.604094 & 0.661645 \\
\hline fs_age & 0.470820 & 0.763794 \\
\hline fs_age & 0.622011 & 0.610580 \\
\hline
\end{tabular}

between boys and girls. Significant differences were found only for maternal authoritative parenting $(t=-1.91 ; p=0.05)$ and maternal neglecting parenting ( $t=2.53 ; p=0.01$ ). Girls reported higher perceptions of maternal authoritative parenting and lower perceptions of maternal neglecting parenting. No significant differences were found for either maternal or paternal authoritarian parenting or permissive parenting. Furthermore, no significant differences were found in terms of paternal authoritative parenting or paternal neglecting parenting.

ANOVA linking parenting styles to the mothers' and fathers' education levels showed significant differences in parental permissiveness. Mothers and fathers were found to be more permissive when they had lower education levels. In addition, paternal authoritarian parenting levels were higher among fathers with lower education levels. The Bonferroni post-hoc test revealed significant differences between permissive mothers with primary studies and those with a university education $\left(F_{(3,423)}=3.11 ; p=0.023\right)$. Mothers with lower education levels were found to be more permissive. The Bonferroni post-hoc test also revealed significant differences in paternal permissive parenting $\left(F_{(3,423)}=2.81 ; p=0.031\right)$ and paternal authoritarian parenting $\left(F_{(3,423)}=3.94 ; p=0.000\right)$. Fathers with higher education levels were more permissive. Fathers with lower education levels had a more authoritarian parenting style, according to adolescents' perceptions.

\section{2 fsQCA of the sample of boys and girls}

The first step when performing fsQCA is to study the necessary conditions. A condition is necessary when the condition has a consistency value of 0.9 or higher, according to fsQCA 3.0 software (Schneider, Schulze-Bentrop, \& Paunescu, 2010). The data in Tables 1 and 2 confirm that no condition was necessary for either boys or girls. Therefore, the next step was to conduct analysis to determine which configurations of conditions were sufficient for the outcome to occur.

\subsection{1 | Girls}

The intermediate solution for girls appears in Table 3. As per the literature, it was assumed that the absence of authoritative parenting and the presence of authoritarian, neglecting, and permissive parenting would lead to heavy Internet use by adolescents. 
TABLE 2 Analysis of necessary conditions for the boy adolescent model

\begin{tabular}{|c|c|c|}
\hline Conditions tested & Consistency & Coverage \\
\hline fs_perm & 0.568482 & 0.731839 \\
\hline$\sim f s \_p e r m$ & 0.539529 & 0.655658 \\
\hline fs_autho & 0.418717 & 0.715270 \\
\hline fs_autho & 0.676769 & 0.667248 \\
\hline fs_control & 0.465497 & 0.730163 \\
\hline$\sim$ fs_control & 0.635224 & 0.660218 \\
\hline fs_negle & 0.522511 & 0.694189 \\
\hline$\sim$ fs_negle & 0.574707 & 0.678542 \\
\hline fs_age & 0.516255 & 0.754970 \\
\hline$\sim f s \_a g e$ & 0.568409 & 0.620630 \\
\hline
\end{tabular}

The first configuration (combination) of conditions was fs_negle*fs_age. According to this configuration, neglecting parenting of adolescent girls aged 17-18 years leads to heavy Internet use as the preferred leisure activity. The second configuration was $\sim f s_{-}$autho* $\sim f s_{-}$control*fs_age. According to this configuration, the absence of authoritative parenting together with the absence of authoritarian parenting leads to heavy Internet use of adolescent girls aged $17-18$ years.

\subsection{2 | Boys}

The intermediate solution for boys appears in Table 4. As per the literature, it was assumed that the absence of authoritative parenting and the presence of authoritarian, neglecting, and permissive parenting would lead to heavy Internet use by adolescents.

The data in Table 4 show that the results for adolescent boys differ considerably from those for adolescent girls. Authoritarian parenting was a necessary condition for heavy Internet use. The third configuration (fs_negle*fs_control*fs_autho*fs_perm) is noteworthy. According to this configuration, the combination of the four parenting styles within the family unit leads to heavy Internet use. This heavy use may owe to contradictions between parenting styles.
Analysis of differences between means for paired samples revealed significant differences between the four paternal and four maternal parenting styles. This finding indicates that levels of maternal authoritative and authoritarian parenting are higher than levels of paternal authoritative and authoritarian parenting. Levels of maternal permissive parenting are lower than levels of paternal permissive parenting, according to the perceptions of adolescent girls and boys. According to adolescent boys, mothers are more uninvolved than fathers are. According to adolescent girls, fathers are more uninvolved than mothers are. Future studies should examine how Internet use relates to the parenting styles of people who are influential in adolescents' daily lives. Overall, the results show that adolescents whose parents adopt incoherent parenting styles choose Internet use as their preferred leisure activity.

\section{5 | DISCUSSION AND CONCLUSIONS}

Internet use is growing among members of the general population, especially among adolescents. Adolescents, particularly boys, report a growing preference to buy online. The Internet is used to buy clothing, games, music, and electronics. Easier Internet access means greater use of social networks such as Instagram, Facebook, and FaceTime. Adolescents intensively use instant messaging services such as WhatsApp and Twitter. This Internet activity is consistent with the behavior reported in the PISA report on Internet use in OECD countries, particularly Spain (OECD, 2015).

The principal conclusions of this study are as follows. First, gender differences in adolescents' Internet use are significant. Girls' and boys' online buying behaviors are similar. The differences relate to playing online games, which boys play more than girls do. Boys also consider the Internet the best way to shop, partly because it is cheap. Boys' buying preferences consist of electronics, games, music, and clothing.

Second, older adolescents make larger online purchases because of their greater purchasing power and access to the job market. Although these jobs may be precarious, they provide income to cover personal

TAB LE 3 Intermediate solution for the girl adolescent model

\begin{tabular}{llll} 
& Raw coverage & Unique coverage & Consistency \\
\hline fs_negle*fs_age & 0.252192 & 0.041990 & 0.831927 \\
\hline fs_autho* fs_control*fs_age & 0.295942 & 0.099299 & 0.826717 \\
fs_control*fs_age*fs_perm & 0.167845 & 0.009366 & 0.917525 \\
\hline
\end{tabular}

Solution coverage: 0.383687

Solution consistency: 0.814009

TAB LE 4 Intermediate solution for the boy adolescent model

\begin{tabular}{|c|c|c|c|}
\hline & Raw coverage & Unique coverage & Consistency \\
\hline fs_age ${ }^{*}$ fs_control*fs_autho & 0.161235 & 0.046560 & 0.865797 \\
\hline 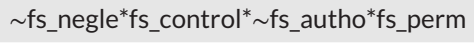 & 0.182387 & 0.073019 & 0.898633 \\
\hline fs_negle*fs_control*fs_autho*fs_perm & 0.167416 & 0.043284 & 0.953242 \\
\hline
\end{tabular}

Solution coverage: 0.303144 .

Solution consistency: 0.880868 . 
expenses. Accordingly, older adolescents like to shop online, purchase more, and perceive it as the best way to shop.

Third, the results show that neglecting parenting encourages indiscriminate Internet use (Hypothesis 1). Whenever they have free time, adolescents access the Internet to such an extent that Internet use consumes most of their day. For these adolescents, the Internet is their main leisure activity. Neglecting parenting implies a lack of support and control coupled with a high degree of permissiveness, which sends messages of rejection toward the child. Neglecting parents are characterized by a lack of warmth toward their children. In this situation, children perceive the Internet as an easy way of receiving support and comprehension (Eastin et al., 2006). Adolescents are drawn toward the Internet because it offers them an emotional response to their needs and lets them feel understood and accepted by other Internet users (Orford, 2001; van Den Eijnden et al., 2010). These findings are consistent with those reported by Huang et al. (2010), who found that Internet addicts perceived less emotional warmth and more parental rejection. This situation occurs throughout adolescence. For older adolescent girls (17-18 years), Internet use (compulsive and addictive) as the main leisure activity is related to neglecting parenting. For boys, however, authoritarian parenting has the strongest relationship with compulsive Internet use. Intensive, addictive Internet use among boys also occurs when there is a mix of the four parenting styles. Seemingly, a lack of consistency and disciplinary contradictions between parents steer adolescents toward the Internet (Hypothesis 2). Indeed, interparental inconsistencies negatively affect children's development (García-Linares, Torre, Villa Carpio, Cerezo, \& Casanova, 2014; Serrano, Á., del Barrio, \& Ortiz, 2009).

Fourth, the results show that imposing rules and control without providing explanations about Internet content and use can increase the desire to use the Internet and foment anxiety in adolescents. These parenting practices can encourage compulsive Internet use. Fluent communication about Internet use based on parents' trust in children is an effective tool for combating intensive Internet use and guiding children toward rational and responsible Internet use (Liu \& Kuo, 2007; van Den Eijnden et al., 2010). Policymakers should consider these findings when designing family training programs aimed at fostering responsible Internet use.

This study has limitations, which present opportunities for further research. The first limitation relates to the study's cross-sectional nature. The findings could be enriched by longitudinal studies over a longer period to observe the way adolescents' Internet use develops over time. It would be advisable to extend the age range of the participants to analyze the key moments that favor compulsive Internet use. Accordingly, it would be interesting to conduct a study that examined Internet use from middle childhood to (7-8 years) to late adolescence (17-18 years). The second limitation of the study relates to the data source and data collection procedure. The analysis was based on self-report data from adolescents. Studies have shown that adolescents' self-report data on parenting styles are more reliable than data from parents (Gaylord, Kitzmann, \& Coleman, 2003), which are more sensitive to social desirability problems (Roa \& Del Barrio, 2001). Nevertheless, the analysis could be improved if both data sources (parents and children) were considered. A third limitation relates to the questionnaire and the factors that it measured. The questionnaire could be improved by including additional variables and studying parenting styles and parenting practices as well as children's trust in parents.

\section{REFERENCES}

Roa Capilla, L., \& Barrio, V. D. (2001). Adaptación del cuestionario de crianza parental (PCRI-M) a población española. Revista Latinoamericana de Psicología, 33(3), 329-341.

Gaylord, N. K., Kitzmann, K. M., \& Coleman, J. K. (2003). Parents' and children's perceptions of parental behavior: Associations with children's psychosocial adjustment in the classroom. Parenting: Science and Practice, 3(1), 23-47.

Ak, S., Koruklu, N., \& Yilmaz, Y. (2013). A study on Turkish adolescent's internet use: Possible predictors of internet addiction. Cyberpsychology, Behavior, and Social Networking, 16, 205-209.

Bandura, A. (1986). Social foundations of thought and action: A social cognitive theory. Englewood Cliffs, NJ: Prentice-Hall.

Bandura, A. (2006). Toward a psychology of human agency. Perspectives on Psychological Science, 1(2), 164-180.

Baudrillard, J. (2007). La Sociedad de Consumo: Sus mitos, sus estructuras (4th ed.) [The consumer society: Myths and structures]. Madrid, Spain: Siglo XXI.

Baumrind, D. (1991). The influence of parenting style on adolescent competence and substance use. Journal of Early Adolescence, 11(1), 56-95.

Baumrind, D. (1996). The discipline controversy revisited. Family Relations: An Interdisciplinary. Journal of Applied Family Studies, 45(4), 405-414.

Benbassat, N., \& Priel, B. (2012). Parenting and adolescent adjustment: The role of parental reflective function. Journal of Adolescence, 35(1), 163174.

Bronfenbrenner, U. (1987). La ecología del desarrollo humano. Barcelona: Paidós.

Bronfenbrenner, U. (2005). The bioecological theory of human development. In U. Brofenbrenner (Ed.), Making human beings human: Bioecoogical perspectives on human development (pp. 3-15). Thousand Oaks: CA: Sage.

Chou, C., \& Lee, Y. H. (2017). The moderating effects of internet parenting styles on the relationship between Internet parenting behavior, Internet expectancy, and Internet addiction tendency. The AsiaPacific Education Researcher, 26(3-4), 137-146. https://doi.org/10.1007/ s40299-017-0334-5

Critselis, E., Janikian, M., Paleomilitou, N., Oikonomou, D., Kassinopoulos, M., Kormas, G., \& Tsitsika, A. (2013). Internet gambling is a predictive factor of internet addictive behavior. Journal of Behavioral Addictions, 2, 224-230.

Darling, N., \& Steinberg, L. (1993). Parenting style as context: An integrative model. Psychological Bulletin, 113(3), 487-496.

Eastin, M. S., Greenberg, B. S., \& Hofschire, L. (2006). Parenting the internet. Journal of Communication, 56(3), 486-504.

Ferreiro, S. G., Salgado, P. G., Harris, S. K., Tobío, T. B., \& Boubeta, A. R. (2017). Diferencias de sexo en el uso de internet en adolescentes españoles [Gender differences in the use of the Internet in Spanish adolescents]. Psicología Conductual, 25(1), 129-146.

Fiss, P. C. (2011). Building better causal theories: A fuzzy set approach to typologies in organization research. Academy of Management Journal, 54(2), 393-420

García-Linares, M. C., de la Torre, M. J., de la Villa Carpio, M., Cerezo, M. T., \& Casanova, P. F. (2014). Consistencia/Inconsistencia en los estilos educativos de padres y madres, y estrés cotidiano en la adolescencia [Consistency/inconsistency in maternal and paternal parenting styles 
and daily stress in adolescence]. Revista de Psicodidáctica, 19(2), 307325. Retrieved from https://ehu.es/revista-psicodidactica

Gonçalves, H. M., Rey-Martí, A., Roig-Tierno, N., \& Miles, M. P. (2016). The role of qualitative research in current digital social media: Issues and aspects-An introduction. Psychology \& Marketing, 33(12), 1023-1028.

Grusec, J. E., Goodnow, J. J., \& Kuczynski, L. (2000). New directions in analyses of parenting contributions to children's acquisition of values. Child Development, 71(1), 205-211.

Hoffman, M. (2002). Desarrollo moral y empatía: Implicaciones para la atención y la justicia [Empathy and moral development: Implications for caring and justice]. Barcelona: Idea Books.

Huang, C. M., Chan, E., \& Hyder, A. A. (2010). Web 2.0 and internet social networking: A new tool for disaster management?-lessons from taiwan. BMC medical informatics and decision making, 10(1), 57.

Jiménez, A. G. (2011). Una perspectiva sobre los riesgos y usos de internet en la adolescencia [A perspective of Internet risks and uses in adoles cence]. Revista ICONO14, 9(3), 410-425.

Kacen, J., Hess, J., \& Walker, D. (2012). Spontaneous selection: The influence of product and retailing factors on consumer impulse purchases. Journal of Retailing and Consumer Services, 19(6), 578-588.

Ko, C. H., Wang, P. W., Liu, T. L., Yen, C. F., Chen, C. S., \& Yen, J. Y. (2015). Bidirectional associations between family factors and Internet addiction among adolescents in a prospective investigation. Psychiatry and Clinical Neurosciences, 69(4), 192-200.

Kuczynski, L., \& Parkin, C. M. (2007). Agency and bidirectionality in socialization: Interactions, transactions, and relational dialectics. In J. E. Grusec \& P. D. Hastings (Eds.), Handbook of socialization: Theory and research (pp. 259-283). New York: The Guilford Press.

Laursen, B., \& Collins, A. W. (2009). Parent-adolescent relationships and influences. In R. M. Lerner \& L. Steinberg (Eds.), Handbook of adolescent psychology. Vol. 2: Contextual influences on adolescent development (3rd ed., pp. 3-42). Hoboken, NJ: Wiley. Retrieved from https://www.is.muni.cz/el/1423/podzim2010/PSY516/um/Laursen Collins1.pdf

Legewie, N. (2013, September). An introduction to applied data analysis with qualitative comparative analysis. Forum: Qualitative Social Research, 14(3).

Liu, C. Y., \& Kuo, F. Y. (2007). A study of Internet addiction through the lens of the interpersonal theory. CyberPsychology \& Behavior, 10(6), 799-804.

Maccoby, E. E., \& Martin, J. A. (1983). Socialization in the context of the family: Parent-child interaction. In P. H. Mussen (Ed.), Handbook of child psychology (Vol. 4, pp. 1-101). New York: Wiley.

MECD. (2017). Programa para la Evaluación Internacional de los Alumnos. El Bienestar de los estudiantes. Spanish Ministry of Education, Culture and Sport. Retrieved from https://www.mecd.gob.es/dctm/ inee/internacional/pisa-2015/informebienestar042517.pdf?documen $\mathrm{tld}=0901 \mathrm{e} 72 \mathrm{~b} 8249 \mathrm{f0} 43$

OECD. (2015). Students' well-being: Results of the PISA 2015 Survey. Retrieved from https://www.oecd.org/pisa/PISA2015-Students-Well -being-Country-note-Spain.pdf

Orford, J. (2001). Addiction as excessive appetite. Addiction, 96(1), 15-31.

Özgür, H. (2016). The relationship between Internet parenting styles and Internet usage of children and adolescents. Computers in Human Behavior, 60, 411-424. https://doi.org/10.1016/j.chb.2016.02.081.

Pujazon-Zazik, M., \& Park, M. J. (2010). To tweet, or not to tweet: Gender differences and potential positive and negative health outcomes of adolescents' social internet use. American Journal of Men's Health, 4, 77-85.
Ragin, C. C., \& Fiss, P. (2008). Net effects analysis versus configurational analysis: An empirical demonstration. In C.C. Ragin (Ed.), Redesigning social inquiry: Fuzzy sets and beyond (pp. 190-212). Chicago, IL: University of Chicago Press.

Rial, A., Gómez, P., Braña, T., \& Varela, J. (2014). Actitudes, percepciones y uso de internet y las redes sociales entre los adolescentes de la comunidad gallega (España) [Attitudes, perceptions and Internet and social networks use among Galician (Spain) teens]. Anales de Psicología, 30, 642-655.

Ribeiro Soriano, D., \& Huarng, K. H. (2013). Innovation and entrepreneurship in knowledge industries. Journal of Business Research, 66, 19641969.

Rubin, K. H., Wojslawowicz, J. C., Rose-Krasnor, L., Booth-LaForce, C., \& Burgess, K. B. (2006). The best friendships of shy/withdrawn children: Prevalence, stability, and relationship quality. Journal of Abnormal Child Psychology, 34(2), 139-153.

Schaefer, E. S. (1965). Children's reports of parental behavior: An inventory. Child Development, 36(2), 413-424. https://doi.org/10.2307/1126465.

Schneider, M. R., Schulze-Bentrop, C., \& Paunescu, M. (2010). Mapping the institutional capital of high-tech firms: A fuzzy-set analysis of capitalist variety and export performance. Journal of International Business Studies, 41(2), 246-266.

Schneider, C. Q., \& Wagemann, C. (2012). Set-theoretic methods for the social sciences: A guide to qualitative comparative analysis. NY, USA: Cambridge University Press.

Serrano, M., del Barrio, M. V., \& Ortiz, M. A. C. (2009). Consistencia interparental y su relación con la agresión y la sintomatología depresiva en niños y adolescents [Interparental consistency and its relationship to aggression and depression in children and adolescents]. Revista de Psicopatología y Psicología Clínica, 14(1), 51-60. Retrieved from https://www.ehu.es/revista-psicodidactica

Tur-Porcar, A., Mestre, V., \& Llorca, A. (2015). Estilos parentales. Análisis psicométrico en dos estudios en población española [Parenting styles. Psychometric analysis in two studies of the Spanish population]. Anuario de Psicología/The UB Journal of Psychology, 45(3), 347-359.

Tur-Porcar, A., Mestre, V., Samper, P., \& Malonda, E. (2012). Crianza y agresividad de los menores: ¿ es diferente la influencia del padre y de la madre? [Parenting and children's aggression: Are there differences in the influence of the father and the mother?]. Psicothema, 24(2), 284288.

van Den Eijnden, R. J., Spijkerman, R., Vermulst, A. A., van Rooij, T. J., \& Engels, R. C. (2010). Compulsive Internet use among adolescents: Bidirectional parent-child relationships. Journal of Abnormal Child Psychology, 38(1), 77-89.

Xiuqin, H., Huimin, Z., Mengchen, L., Jinan, W., Ying, Z., \& Ran, T. (2010). Mental health, personality, and parental rearing styles of adolescents with Internet addiction disorder. Cyberpsychology, Behavior, and Social Networking, 13(4), 401-406.

Zimmer-Gembeck, M. J., Waters, A. M., \& Kindermann, T. (2010). A social relations analysis of liking for and by peers: Associations with gender, depression, peer perception, and worry. Journal of Adolescence, 33(1), 69-81.

How to cite this article: Tur-Porcar A. Parenting styles and Internet use. Psychol Mark. 2017;34:1016-1022. https://doi. org/10.1002/mar.21040 